Article

\title{
Evaluation of FAO-56 Penman-Monteith Model Using Alternative Climatic Data Application to Afghanistan
}

\author{
Homayoon Ganji $^{1}$ (D) , T. Kajisa ${ }^{1}$ \\ ${ }^{1}$ Graduate School of Bioresources, Mie University, Tsu City, Japan.
}

Received: 21 December 2018 - Accepted: 18 March 2019

\begin{abstract}
The Penman-Monteith model with alternative and measured data in three regions of Afghanistan (Central-North- East) was discussed by estimating reference evapotranspiration $\left(E T_{0}\right)$. The result showed that in the high rate of $E T_{0}$, the difference between $E T_{0}$ that estimated using alternative and measured data could be more than $2 \mathrm{~mm} \mathrm{day}^{-1}$ when using alternative humidity and wind data in the Central region. Because there is a windy season in the Central region only, the results seem to mean that one of the cases, the impact of the windy season on the Penman-Monteith model, has been found. The alternative solar radiation was effective in any region.
\end{abstract}

Keywords: reference evapotranspiration, FAO-56 Penman-Monteith, alternative data.

\section{Avaliação do Modelo Penman-Monteith FAO-56 Usando Dados Climáticos Alternativos Aplicação para o Afeganistão}

\begin{abstract}
Resumo
O modelo de Penman-Monteith com dados alternativos medidos em três regiões do Afeganistão (Centro-Norte- Leste) foi avaliado estimando-se a evapotranspiração de referência $\left(E T_{0}\right)$. Quando a $E T_{0}$ for alta, a diferença da $E T_{0}$ estimada com dados alternativos ou dados medidos pode ser superior a $2 \mathrm{~mm} /$ dia para dados de umidade e vento na região Central. Como há estação ventosa apenas na região Central, os resultados pareciam indicar que um dos casos do impacto da estação ventosa no modelo de Penman-Monteith havia sido encontrado. A radiação solar como dado alternativo foi eficaz em qualquer região.
\end{abstract}

Palavras-chave: evapotranspiração de referência, Penman-Monteith (FAO-56), dados alternativos.

\section{Introduction}

The Penman-Monteith method is adopted in FAO Irrigation and Drainage Paper no. 56, known as (FAO$56 \mathrm{PM})$. FAO recommends this method as a global standard based on meteorological data Allen et al. (1998), and it has been found the best when applied in various regions with complete required data Allen et al. (1989); Allen and Pruitt (1991); Garcia et al. (2004); Ganji et al. (2017). The FAO-56PM equation is a combination method made up of two terms, the radiation, and aerodynamic terms. The radiation term depends on the solar radiation, while the aerodynamic term depends on the air temperature, wind speed, and the vapor pressure deficit. However, to estimate
$E T_{0}$ using FAO-56PM equation, complete input data are required Allen et al. (1998).

The FAO-56PM equation requires data concerning the maximum and minimum temperature $T_{\max }$ and $T_{\min }$, respectively), relative humidity $(R H)$, solar radiation $\left(R_{S}\right)$, and wind speed $\left(u_{2}\right)$ measured two meters above ground level Allen et al. (1998). While most of the stations around the world, especially in developing counties, are not equipped to supply this complete set of weather variables Droogers and Allen (2002); Gocic and Trajkovic (2010), this is a severe restriction to the application of the FAO56PM equation Popova et al. (2006), especially in Afghanistan where such metrological variables are often missing or of questionable quality. To overcome this restriction,

Corresponding author: Homayoon Ganji, e-mail: homayonganji@gmail.com. 
FAO paper no. 56 supplies procedures that allow the missing variables to be estimated.

The proposed procedures for estimating alternative variables have been tested by many researchers at a variety of locations worldwide and different results have been reported for different climate regimes. Popova et al. (2006) found the procedures proposed by FAO to be accurate when applied in Southern Bulgaria. In a study conducted in Southern Ecuador, Cordova et al. (2015) found that the use of global average wind data had no significant effect on the calculation of $E T_{0}$ but that, when the $R_{S}$ data were missing, the $E T_{0}$ calculations became erroneous. A study in Southern Ontario, Canada, conducted by Sentelhas et al. (2010), reported that when $R H$ and $E T_{0}$

The earlier studies were done in various locations worldwide; however, none of them conducted in Afghanistan. It is, therefore, essential to evaluate the performance of the FAO-56PM model with alternative data considering the seasonal variation of the climate conditions in three regions in Afghanistan. Details about the regions are given in Table 1. This study follows two objectives: (i) To evaluate the performance of the FAO-56 PM model with alternative data in three regions of Afghanistan. (ii) To evaluate the performance of the Hargreaves model as an alternative method for estimating $E T_{0}$ when the only available variable is temperature.

\section{Methodology}

The climatic data were used in the computation, provided by automatic weather stations that have recently been launched in the three investigated regions. The stations are operated by the Agriculture Irrigation and Livestock departments in each region. The climate data provided by the stations do not have human error, and records were available at two meters above ground level from April 2016 to March 2017 for estimating $E T_{0}$.

\subsection{The FAO-56PM equation}

The FAO-56 PM equation, which is proposed in FAO paper no. 56, was used to estimate daily average $E T_{0}$ using complete and alternative data. This is given as Eq. (1). The step by step computation procedure of the FAO-56 PM equation is given in FAO paper no. 56, in details.

$$
E T_{0(P M)}=\frac{0.408 \Delta\left(R_{n}-G\right)+\gamma \frac{900}{T+273} u_{2}\left(e_{s}-e_{a}\right)}{\Delta+\gamma\left(1+0.34 u_{2}\right)}
$$

where $E T_{0(P M)}$ is reference evapotranspiration which was calculated using complete climatic data $\left(\mathrm{mmd}^{-1}\right), \Delta$ is the slope of the vapor pressure curve $(\mathrm{kPa}), R_{n}$ is the net radiation $\left(\mathrm{MJ} \mathrm{m}^{-2} \mathrm{~d}^{-1}\right), G$ is the soil heat flux density $\left(\mathrm{MJm}^{-2} \mathrm{~d}^{-1}\right), \gamma$ is the psychrometric constant $\left(\mathrm{kPa}^{\circ} \mathrm{C}^{-1}\right), T$ is daily average air temperature $\left({ }^{\circ} \mathrm{C}\right), u_{2}$ is daily average wind speed $\left(\mathrm{m} \mathrm{s}^{-1}\right), e_{s}$ is the saturation vapor pressure $(\mathrm{kPa})$, and $e_{a}$ is the actual vapor pressure ( $\left.\mathrm{kPa}\right)$.

The Eq. (1) was used to estimate $E T_{0}$ with alternative data also. When $R_{S}$ data was missing, the value that was produced by Eq. (2), substituted in the Eq. (1) to estimate $E T_{0\left(-R_{s}\right)}$. As well as, the value that was obtained from the Eq. (3), substituted for the missing $E_{a}$ in the Eq. (1) to estimate $E T_{0(-R H)}$. The global average $u_{2}$ (defined as $2 \mathrm{~m} \mathrm{~s}^{-1}$ ) was used as alternative in the Eq. (1) for missing of the daily average $u_{2}$ to estimate $E T_{0\left(-u_{2}\right)}$.

\subsection{Alternative data estimation}

In the FAO paper no.56, some procedures are adopted that allow the missing of solar radiation, relative humidity, and wind speed to be estimated. The solar radiation and relative humidity can be estimated using air temperature only, while the missing of wind speed can be substituted by constant global average value of $2 \mathrm{~ms}^{-1}$ Allen et al. (1998). The procedures are described below:

\subsubsection{Solar radiation}

When $R_{S}$ based on hours of sunshine or direct measured data is missing, Hargreaves' radiation formula as a function of $T_{\min }$ and $T_{\max }$ is recommended to be substituted the missing data, this is given as Eq. (2). Hargreaves' radiation formula assumes that the difference between $T_{\min }$ and $T_{\max }$ is governed by the daily solar radiation Hargreaves and Samani (1985). It is abbreviated here in this study as $\left(R_{S(A l t)}\right)$.

$$
R_{s(A l t)}=k_{R s} \sqrt{\left(T_{\max }-T_{\min }\right)} \times R_{a}
$$

where $R_{S(A l t)}$ is the solar radiation based on temperature $(\mathrm{kPa}), k_{R s}$ is the adjustment coefficient $(0.16)$ for an interior area $\left({ }^{\circ} \mathrm{C}^{-0.5}\right), R_{a}$ is the extraterrestrial radiation $\left(\mathrm{MJm}^{-2} \mathrm{~d}^{-1}\right)$.

Table 1 - Station's location, coordinates, and elevations.

\begin{tabular}{lccc}
\hline Locations name & Latitude $(\mathrm{N})$ & Longitude $(\mathrm{E})$ & Elevation $(\mathrm{m})$ \\
\hline Parwan (Central region) & $35^{\circ} 04^{\prime}$ & $69^{\circ} 18^{\prime}$ & 1,573 \\
Samangan (North region) & $35^{\circ} 83^{\prime}$ & $67^{\circ} 78^{\prime}$ & 959 \\
Jalalabad (East region) & $34^{\circ} 25^{\prime}$ & $70^{\circ} 28^{\prime}$ & 580
\end{tabular}




\subsubsection{Relative humidity}

When $R H$ data are unavailable, the actual vapor pressure $\left(e_{a}\right)$ can be calculated on the assumption that $T_{\text {min }}$ is close to $T_{d e w}$, this is given as Eq. (3). This might be true in humid areas, where the difference between $T_{\min }$ and $T_{\text {dew }}$ is small. In arid areas, however, there is often a large difference between $T_{\text {min }}$ and $T_{\text {dew }}$ Kimball et al. (1997).

$$
e_{a(A l t)}=0.611 e^{\left(\frac{17.27 \times T_{\min }}{T_{\min }+273.3}\right)}
$$

where $e_{a(A l t)}$ is the actual vapor pressure estimated using minimum temperature $(\mathrm{kPa})$.

\subsubsection{Wind speed}

When $u_{2}$ data are lacking, two alternative approaches are recommended: either the default world average value of $u_{2}=2 \mathrm{~ms}^{-1}$ is used or $u_{2}$ data from a nearby station are used if available Allen et al. (1998). In this study, the default world average value was used.

\subsection{Statistical analysis}

In accordance with earlier studies, i.e. Sentelhas et al. (2010); Cordova et al. (2015); Popova et al. (2006), regression analysis was used to evaluate the performance of the $E T_{0(P M)}$ and those estimated using alternative data. The linear coefficient forcing through the origin $a=0$. The regression slope $(b)$ was used as the measure of the accu-
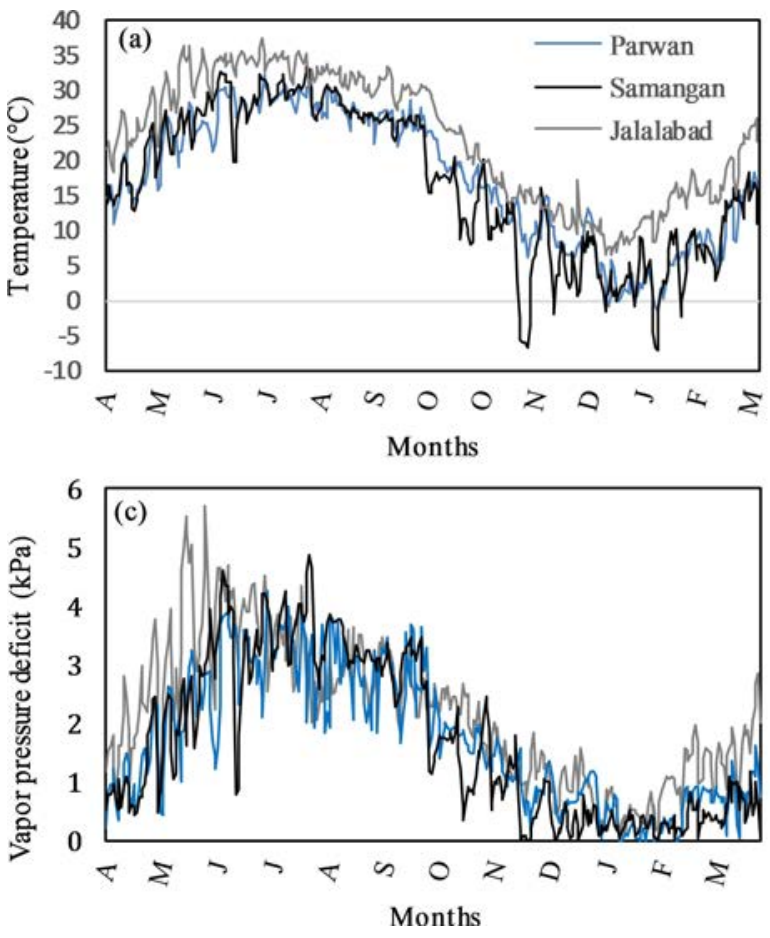

racy, and the coefficient of determination $\left(R^{2}\right)$ the was used as the measure of the exactness.

\section{Results}

The seasonal variation of the climatic variables that are necessary to estimate $E T_{0}$, shown in Fig. 1 from a to d. The similar shape of the time-series data curves of $T, R_{S}$ and vapor pressure deficit (VPD) were identical with small variation all over the course of the study period in all three locations (Fig. 1 from a to $\mathrm{c}$ ).

With respect to the climate conditions of the study locations, $E T_{0}$ was estimated using alternative data of $R_{s}$, $R H$, and $u_{2}$ separately in each location. The estimation of $E T_{0\left(R_{s}\right)}$ was identical to $E T_{0(P M)}$, while $E T_{0\left(e_{a}\right)}$ and $E T_{0\left(u_{z}\right)}$ underestimated $E T_{0(P M)}$, especially for the high estimation rate, in the case of Central region all over the course of the study period (Fig. 2a). The estimation of $E T_{0\left(R_{s}\right)}, E$ $T_{0\left(e_{a}\right)}$ and $E T_{0\left(u_{z}\right)}$ were identical to $E T_{0(P M)}$ in the case of North region throughout the study period (Fig. 2b). The estimation of $E T_{0\left(R_{s}\right)}$ and $E T_{0\left(e_{a}\right)}$ were identical to $E T_{0(P M)}$ in the case of East region, while $E T_{0\left(u_{2}\right)}$ slightly overestimated $E T_{0(P M)}$, especially for the low estimation rate, during the entire of the study period (Fig. 2c).

\section{Discussion}

The seasonal differences between the locations was seen based on $u_{2}$ greater than $3 \mathrm{~ms}^{-1}$ and below $5 \mathrm{~ms}^{-1}$ is
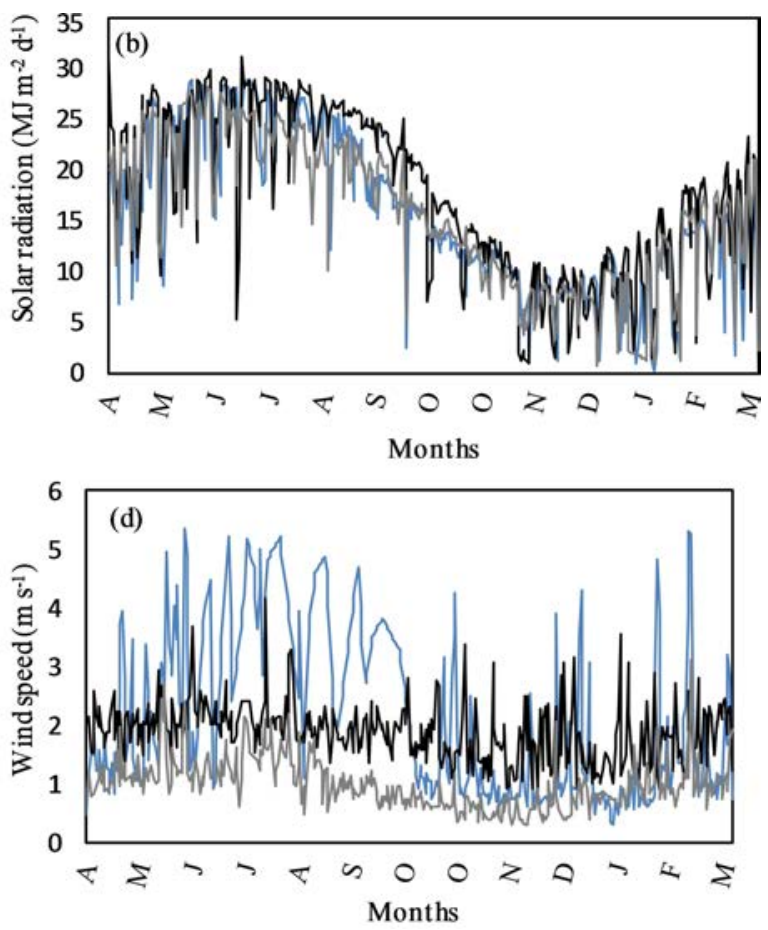

Figure 1 - Daily average measurement of metrological data of (a) air temperature, (b) solar radiation, (c) vapor pressure deficit and (c) wind speed (2016. $4 \sim 2017.3)$. 

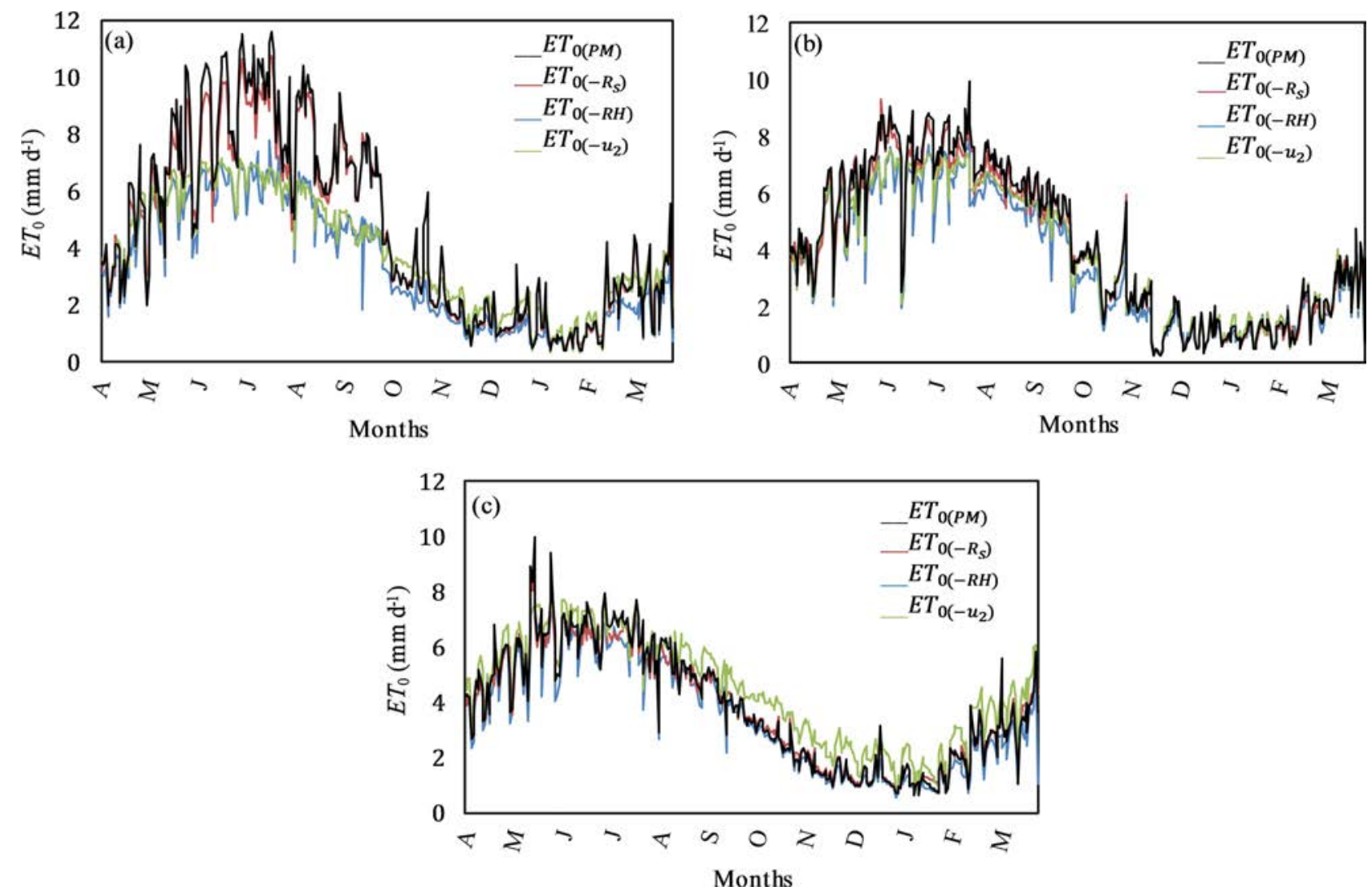

Figure 2 - Daily average estimation of $E T_{0(P M)}$ and those estimated using alternative data (a) Central region, (b) North region, and (c) East region (2016. 4 $\sim 2017.3$ ).

called gentle-moderate wind speed, while below $3 \mathrm{~ms}^{-1}$ can be called light wind speed (Table 2). Therefore, the study locations were classified in two different climate conditions with respect to the seasonal variation of the $u_{2}$ rate. (i) gentle-moderate wind speed conditions which was observed over the half of the course of a year in Central region. (ii) light wind speed conditions which was observed in the North and East regions.

From the assessment of the climate conditions with respect to the key variables, we found the rate of $E T_{0}$ highly dependent upon the wind rate in the three regions. The highest rate of wind speed was observed in the Central Region followed by the North and East Regions (Fig. 1d). The same sequential relationship was confirmed in the case of $E T_{0}$ estimation as well (Fig. 2 form a to c).

Figure 3 shows the plots of estimated $E T_{0(P M)}$ versus those estimated using alternative data in all three study regions. The $R^{2}$ has been widely used to evaluate the "goodness-of-fit" of the $E T_{0}$ equations. However, it does not show the accuracy of an estimation unless to use the value of the slop $(b)$ of the trend line. For instance, comparison of the equation based on $R^{2}$ values alone give a false impression that the estimation of $E T_{0\left(e_{a}\right)} E T_{0\left(u_{z}\right)}$ with $R^{2} \geq 0.80$ are good in all three regions. But the value of $(b \leq 0.61)$ showed that the accuracy of the estimations was weak in the Central Region when $u_{2}$ data was missing, compare to the North and East regions (Figs. 3d and 3g).

The wind speed and $V P D$ are combined as $\left[u_{2} \times V P D\right]$ in Eq. (1). This combination shows if a small difference or weakness that is produced in VPD when using alternative data, will become greater in higher wind speed conditions, this can be the reason of the poor performance of $E T_{0}$ in the case of gentle-moderate windy season in Central Region (Fig. 3d). Therefore, the measurement

Table 2 - Seasonal climatic conditions with respect to the wind speed, using the US weather bureau category.

\begin{tabular}{ll}
\hline Locations & Seasonal climate conditions \\
\hline Parwan & Gentle-moderate wind speed $\left(5 \mathrm{~ms}^{-1}>u_{2}>3 \mathrm{~ms}^{-1}\right.$ until Oct $)$ and Light wind speed $\left(u_{2}<3 \mathrm{~ms}^{-1}\right.$ after Oct $)$ \\
Samangan & Light wind speed $\left(u_{2}<3 \mathrm{~ms}^{-1}\right)$ \\
Jalalabad & Light wind speed $\left(u_{2}<3 \mathrm{~ms}^{-1}\right)$
\end{tabular}


Central Region
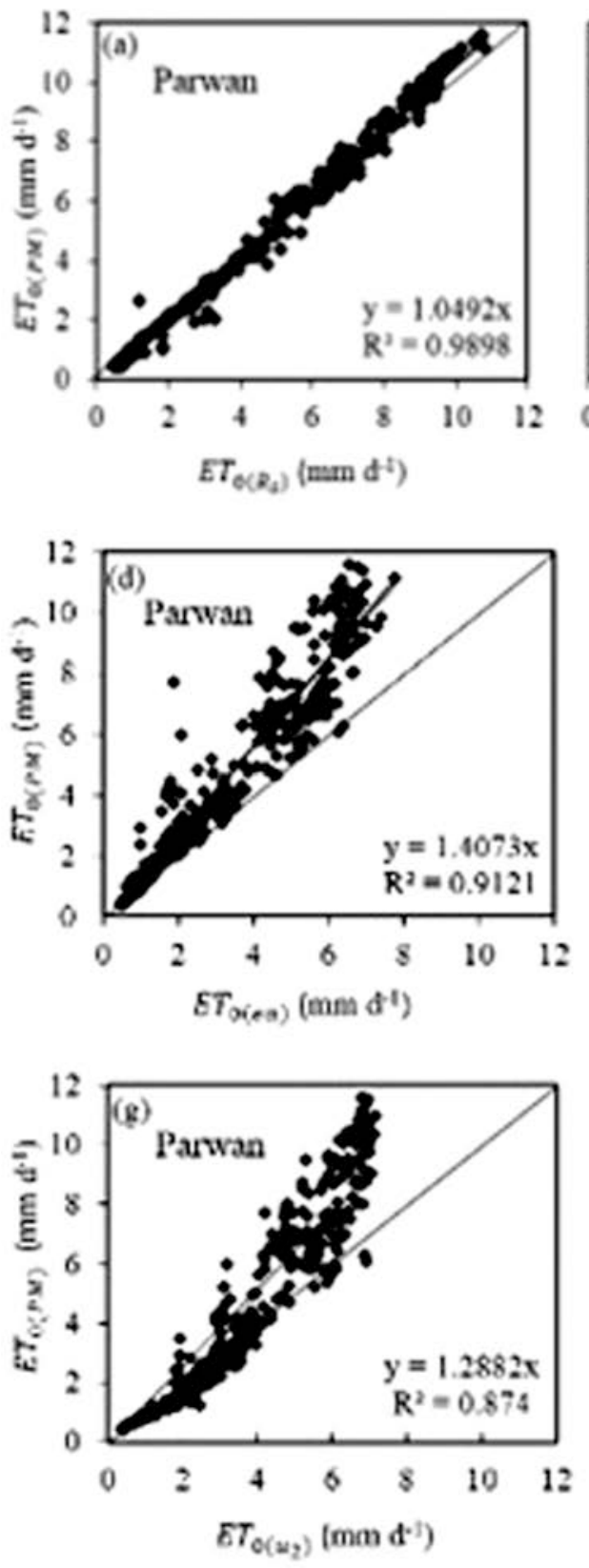

North Region
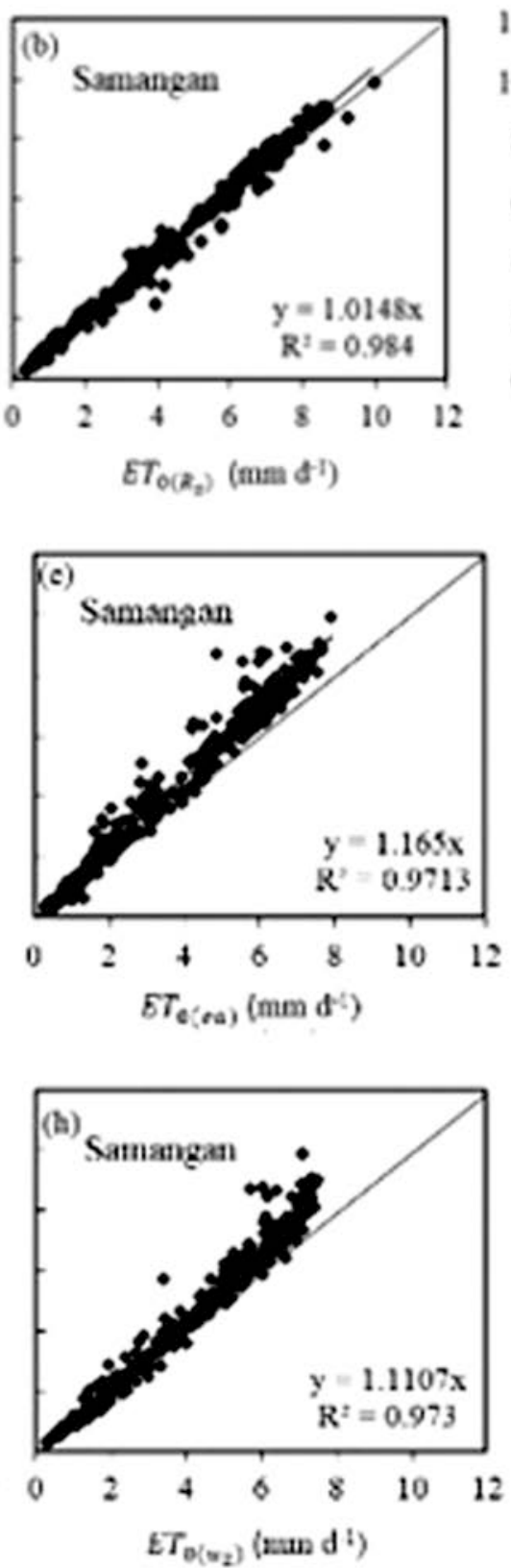

East Region
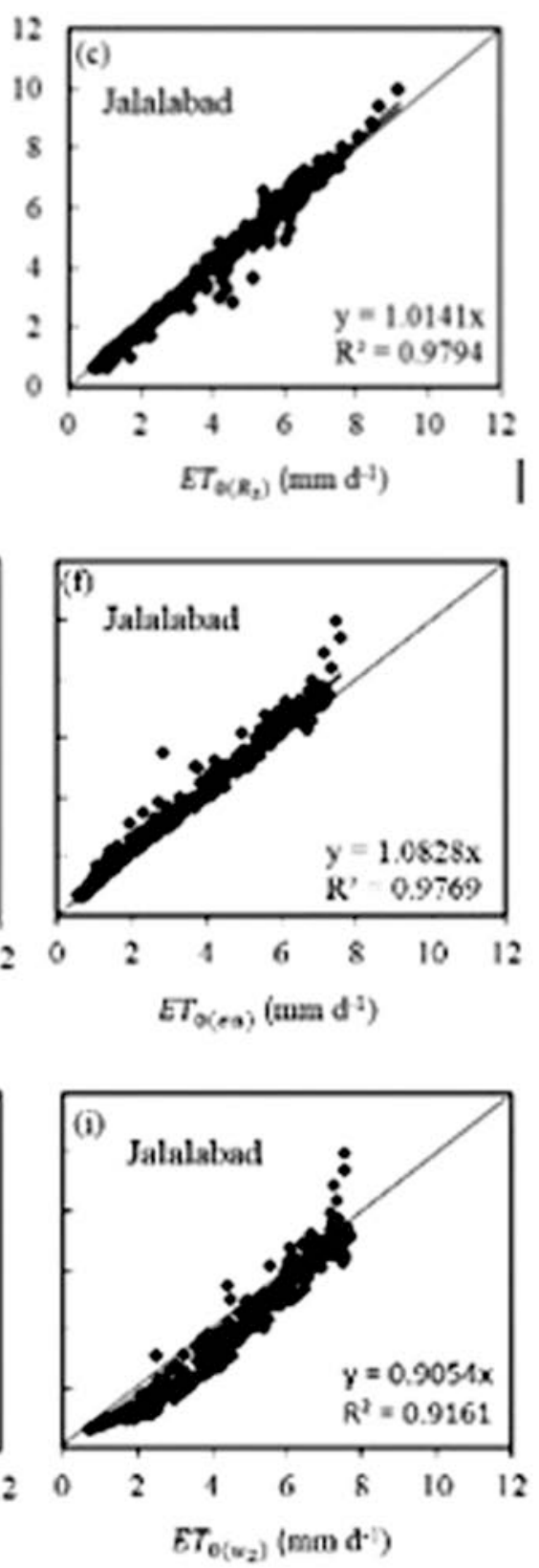

Figure 3 - Comparison between $E T_{0(P M)}$ and those of $E T_{0(A l t)}$.

of $\mathrm{RH}$ and $u_{2}$ is essential rather than using the alternative data in such a climate conditions.

\section{Conclusions}

The $E T_{0}$ calculation is needed when determining water requirement of the crop for irrigation scheduling. The Eq. (1) as a standard method which offering high accuracy, is used widely for estimating $E T_{0}$. The datademands to calculate using this method is a big limitation in locations where are facing with data scarcity such as the case of Afghanistan. When the climatic variables for estimating $E T_{0}$ is not sufficient, alternative data has been recommended for missing variables. The alternative data of solar radiation, humidity, and wind speed can be obtained from the procedures adopted in FAO paper no. 56. In this study, the performance of the Eq. (1) when calculated using alternative data, was assessed with respect to the climate conditions in three different regions in Afghanistan. 
Form the results we have found that the estimations of $E T_{0}$ with alternative data of solar radiation were good with significant accuracy based on the statistical indices given by regression analysis $\left(R^{2}>0.98\right.$ and $b$ close to unity). The estimation of $E T_{0}$ with alternative $e_{a}$ was found less accurate in the Central and North regions, while it was significantly accurate in the East region $\left(R^{2}>0.97\right.$ and $b$ close to unity). The estimation of $E T_{0}$ with $u_{2(A l t)}$ was found with significant less accuracy in the Central with $R^{2}>0.87$ and $b>1.28$. As well as, the accuracy of the $E T_{0}$ estimation was not highly good in the East region $\left(R^{2}>0.87\right.$ and $\left.b>1.86\right)$.

\section{References}

Allen-Richard, G.; Pereira-Luis, S.; Dirk, R.; Martin, S. FAO irrigation and drainage paper No. 56. Rome. Journal of Food and Agriculture Organization of the United Nations, v. 56, p. 97-156, 1998.

Allen, R.G.; Jensen, M.E.; Wright, J.L.; Burman, R.D. Operational estimates of reference evapotranspiration. Journal of Agronomy, v. 81, n. 4, p. 650-662, 1989.

Allen, R.G.; Pruitt, W.O. FAO-24 reference evapotranspiration factors. Journal of irrigation and drainage engineering, v. 117, n. 5 , p. $758-773,1991$.

Garcia, M.; Raes, D.; Allen, R.; Herbas, C. Dynamics of reference evapotranspiration in the Bolivian highlands (Altiplano). Journal of Agricultural and Forest Meteorology, v. 125, n. 1-2, p. 67-82, 2004.

Cordova, M.; Galo, Carrillo-Rojas; Patricio, C.; Bradford, W.; Rolando, C. Evaluation of the Penman-Monteith (FAO 56 PM) method for calculating reference evapotranspiration using limited data application to the wet Páramo of Ecuador. Journal of Mountain Research and Development, v. 35, n. 3, p. 230-39, 2015.
Droogers, P.; Allen-Richard, G. Estimating reference evapotranspiration under inaccurate data conditions. Journal of Irrigation and Drainage Systems, v. 16, n. 1, p. 33-45, 2002.

Ganji, H.; Kajisa, T.; Kondo, M.; Ito, R.; Rostami, B. Re-examining the validity of reference evapotranspiration estimation in Herat, Afghanistan. Journal of GEOMATE, v. 12 n. 30, p. 61-68, 2017.

Gocic, M.; Trajkovic, S. Software for estimating reference evapotranspiration using limited weather data. Journal of Computers and Electronics in Agriculture, v. 71, n. 2, p. 158-162, 2010.

Hargreaves, G.H.; Samani, Z.A. Reference crop evapotranspiration from temperature. Journal of Applied Engineering in Agriculture, v. 1, n. 2, p. 96-99, 1985.

Kimball, J.S.; Running, S.W.; Nemani, R. An improved method for estimating surface humidity from daily minimum temperature. Journal of Agricultural and Forest Meteorology, v. 85, n. 1-2, p. 87-98, 1997.

Pereira, A.R.; Pruitt, W.O. Adaptation of the Thornthwaite scheme for estimating daily reference evapotranspiration. Journal of Agricultural Water Management, v. 66, p. 251-257, 2004.

Popova, Z.; Milena, K.; Luis, S.P. Validation of the FAO methodology for computing ETo with limited data, Application to South Bulgaria. Journal of Irrigation and Drainage, v. 55, n. 2, p. 201-215, 2006.

Sentelhas, P.C.; Terry, J.G.; Eduardo, A.S. Evaluation of FAO Penman-Monteith and alternative methods for stimating reference evapotranspiration with missing data in southern Ontario, Canada. Journal of Agricultural Water Management, v. 97, n. 5, p. 635-44, 2010.

License information: This is an open-access article distributed under the terms of the Creative Commons Attribution License (type CC-BY), which permits unrestricted use, distribution and reproduction in any medium, provided the original article is properly cited. 